\title{
Relationship between \\ the pre- and postpartum body condition scores and periparturient indices and fertility in high-yielding dairy cows
}

\author{
Barbara Stefańska ${ }^{1}$, Agnieszka Poźniak ${ }^{1}$, Włodzimierz Nowak ${ }^{1}$ \\ Department of Animal Nutrition and Feed Management, Faculty of Animal Science, \\ University of Life Sciences, 60-637 Poznan, Poland \\ basianowak88@wp.pl
}

Received: August 3, 2015

Accepted: February 17, 2016

\begin{abstract}
Introduction: The aim of this study was to investigate the relationship between body condition score (BCS) determined on the dry-off day, calving day, and in the first month of lactation, its changes during the dry period and early lactation, and periparturient indices and fertility in high-producing dairy cows. Material and Methods: The experiment was conducted in two herds: A and B, located in Western Poland. The studies were conducted on 116 and 108 Polish Holstein-Friesian dairy cows respectively, with an average milk yield of $>10000 \mathrm{~kg} / 305$-day lactation. The experiment included the dry period $(-56 \mathrm{~d}$ to the calving day), the calving day, and early lactation (from +1 to $+56 \mathrm{~d}$ ). The experimental factor was BCS ( 0 to 5 -point scale). The BCS was performed by one person on day -56 , on parturition day (in the first $12 \mathrm{~h}$ after calving) and on day 30 of lactation. Results: A decrease in BCS $(\geq-0.25)$ in herd A during the dry period accelerated the planned calving period by $7.3 \mathrm{~d}$. In the group of cows with BCS $<3.25$ on the dry-off day, the lowest artificial insemination index (1.80), the shortest period of insemination services $(25 \mathrm{~d})$, and days open $(87 \mathrm{~d})$ were recorded. Moreover, cows with BCS $<3.25$ at calving had the shortest days open $(91 \mathrm{~d})$. BCS $>3.50$ in the first month of lactation $(30 \mathrm{~d})$ resulted in the extension of uterine involution period (56 d). Improvement of BCS during the dry period shortened the anoestrus $(60 \mathrm{~d})$ in herd A and the period of insemination service $(60 \mathrm{~d})$ in herd B. However, in this group (IM BCS $\geq 0.25$ ) of cows the day of the highest artificial insemination index $(2.50)$ in herd B was analysed. Conclusion: The body condition on the dry-off day and at calving, as well as its deterioration in the first month of lactation, have a considerable effect on fertility indices in dairy cows, thus confirming the advisability of its regular monitoring during routine operations connected with the management of a dairy cattle herd.
\end{abstract}

Keywords: dairy cows, body condition score, fertility, transition period.

\section{Introduction}

Currently the primary objectives in dairy cattle rearing and breeding are connected, first of all, with the maintenance of high herd fertility (7). Important parameters, dependent on the energy status of cows in the periparturient period and characterising this trait after calving, include e.g. the development of the dominant ovarian follicle, which takes place by the $40^{\text {th }} \mathrm{d}$ before ovulation, and the incidence of the first oestrus postpartum (15). In cows with the normal course of all physiological processes the $1^{\text {st }}$ oestrus is observed 20 $30 \mathrm{~d}$ after calving and its cyclicity (cycle, every 19-24 d) increases the chance of oestrus prior to insemination (approx. 60-70 d after calving). The primary cause of the delay in the return to ovarian activity is connected with the negative energy balance in the periparturient period (8), while the main method applied worldwide to assess the energy status of high-producing dairy cows is the body condition score (BCS). Indication of optimal body condition values at critical times of the production cycle (the dry period, calving day, onset of early lactation) seems to be crucial for a more precise management of dairy cattle herds. Regular evaluation of body reserves facilitates assessment of the cow nutrition regime and feed ration balance, which, in turn, enables to utilise the production potential of cows and obtain optimal milk yields. Body condition monitoring is also important in 
the prevention of metabolic disorders in the periparturient period and post parturition complications (3). Numerous researchers are of an opinion that the specification of recommended BCS profile of highproducing cows could limit the incidence of a negative energy balance, which is one of the most important causes of the deterioration of fertility indices $(9,27)$.

The aim of this study was to investigate the relationship between the BCS determined on the dry-off day, calving day, and in the first month of lactation (30 d), its changes during dry period and early lactation, and periparturient indices and fertility in high-producing dairy cows. We hypothesised that the BCS may define periparturient indices and fertility in dairy cows.

\section{Material and Methods}

Study design and animals. The experiment was conducted in two herds: $\mathrm{A}$ and $\mathrm{B}$, located in western Poland. The experimental material comprised 116 and 108 clinically healthy dairy cows of Polish Holstein-Friesian breed with average milk yield of $>10000 \mathrm{~kg} / 305$-day lactation. The experiment included the dry period ( $-56 \mathrm{~d}$ to calving day), calving day, and early lactation (from +1 to $+56 \mathrm{~d}$ ). The experimental factor was BCS (0 to 5-point scale). The BCS was determined by one person according to the methodology of Edmonson et al. (10) on -56 d (on the dry-off day), on the parturition day (in the first $12 \mathrm{~h}$ after calving), and on d 30 of lactation. The cows were divided into three groups according to the results of BCS determined in the dry period, on the calving day, and during the first month of lactation $(30 \mathrm{~d})$. These three groups comprised animals which were classified as good (OK, BCS 3.0 3.25), medium (MID, BCS 3.26-3.5), or overfed (FAT, $\mathrm{BCS}>3.5)$. The same cows were further divided into three groups based on the changes in BCS in the periods from drying-off to the calving day, and the first month of lactation $(30 \mathrm{~d})$. The animals were grouped as follows: the group with no changes observed $(\mathrm{NC}, \mathrm{BCS}<0.25$ ), deterioration ( $\mathrm{DE}, \mathrm{BCS} \geq-0.25$ ), and improvement (IM, $\mathrm{BCS} \geq 0.25)$.

Periparturient indices and fertility. In the course of the experiment, the periparturient indices were monitored, e.g. the course of parturition, which was assessed on a five-point scale according to Adamski (1), where: 1 point - normal, unassisted calving, 2 points easy calving, controlled by a handler, 3 points dystocia, human-assisted, 4 points - dystocia, intervention of a veterinarian, 5 points - very difficult calving, calf stillborn or dead within the first hours after calving. Moreover, in herd A, uterine involution was assessed and colostrum quality was evaluated based on its specific gravity determined using a colostrum meter according to Stefaniak and Jawor (30).

Fertility of cows was determined on the basis of the following indices: anoestrus (number of days from calving to first service), the date of the first postpartum oestrus (number of days from calving to the first postpartum oestrus), the period of insemination services (number of days from the first artificial insemination service to effective insemination), days open (number of days from calving to the next fertilisation), and insemination index (number of artificial insemination services required for effective insemination). The first ovulation was identified by transrectal ultrasonography using a colour Doppler ultrasound scanner (SSD-5500, Aloka Co., Japan) equipped with a $7.5-\mathrm{MHz}$ convex transducer (UST-995-7.5, Aloka Co. Japan) (15).

Nutrition. The diets were calculated based on the analysed nutrient contents using the MAX System for dairy cattle programme (Cargill) in accordance with the Nutrient Requirements of Dairy Cattle (NRC, 2001), with feed based on silages from corn, pressed sugar beet pulp, alfalfa, ensiled corn grain, fresh distiller's grain, corn pulp, concentrates (corn, rapeseed meal), and mineral and vitamin supplements (Tables 1, 2). Using wet chemistry analysis, weekly forage, concentrate and TMR samples were tested monthly for crude protein (CP, method no. 976.05), neutral detergent fibre (NDF, method no. 942.05), non-fibre carbohydrates (NFC: method no. 64.785), calcium (Ca, method no. 6869), phosphorus (P, method no. 6491), and potassium (K, method no. 6869). Diets were fed as the total mixed ration (TMR) at 9 a.m. and $2.30 \mathrm{p} . \mathrm{m}$. for the entire experimental period.

Statistical analysis. The effect of lactation number and assessed BCS on analysed traits was estimated using the multivariate analysis of variance (procedure GLMSAS v. 9.4. 2014). The significance of the differences between experimental groups was tested by means of Duncan's test at $\mathrm{P} \leq 0.05-$ means with identical superscripts do not differ significantly $(\mathrm{P}>0.05)$. The standard error of the mean (SEM) was adopted as a measure of error.

\section{Results}

Analyses of the BCS in cows on calving day and its changes during dry period showed no statistically significant differences $(\mathrm{P}>0.05)$ between the BCS and the course of calving in both herds. However, some not statistically significant positive dependence between the BCS of cows on the calving day in the MID group (3.26-3.50 BCS) and the course of calving and negative dependence between deterioration in BCS ( $\mathrm{DE} \geq-0.25$ ) during the dry period and that trait were observed (Tables 3, 4). Moreover, a decrease in BCS (DE $\geq-0.25)$ during the dry period in herd A accelerated the planned date of calving by $7.3 \mathrm{~d}$ with the significant difference confirmed statistically $(\mathrm{P} \leq 0.05)$. In our study, no statistically significant effect $(\mathrm{P}>0.05)$ of $\mathrm{BCS}$ or its changes on colostrum quality in the investigated periods was found. 
Table 1. Composition and nutritive value of feed rations - herd A

\begin{tabular}{|c|c|c|c|c|}
\hline Components (kg/SM) & Dry period $\operatorname{diet}^{1}$ & Close-up diet ${ }^{2}$ & $\begin{array}{l}\text { Fresh diet }^{3} \\
(34 \mathrm{~kg} \mathrm{milk})\end{array}$ & $\begin{array}{l}\text { Lactation diet } \\
\text { (37 kg milk) }\end{array}$ \\
\hline Corn silage & 1.4 & 5.58 & 5.26 & 7.72 \\
\hline Pressed sugarbeet pulp silage & - & 1.10 & 1.32 & 1.76 \\
\hline Alfalfa silage & - & 0.71 & - & - \\
\hline Haylage & 4.86 & - & 1.20 & 1.20 \\
\hline Straw - wheat & 0.89 & 1.34 & 1.34 & 1.34 \\
\hline Fresh distiller's grain & - & 1.15 & 1.15 & 0.92 \\
\hline Corn - meal & - & 0.43 & 0.86 & - \\
\hline Corn - ensiled grain & - & 0.35 & 0.70 & 3.29 \\
\hline FB $21 \% \mathrm{CP}$ & - & 1.33 & 6.63 & 7.97 \\
\hline BFMS & 0.15 & 0.61 & - & - \\
\hline Corn pulp & - & - & 1.59 & 1.91 \\
\hline Rapeseed meal & 0.88 & 0.44 & - & - \\
\hline Glycerin & - & 0.37 & 0.37 & - \\
\hline Rock salt & 0.01 & - & - & 0.01 \\
\hline \multicolumn{5}{|l|}{ Nutrients value (in $1 \mathrm{~kg} \mathrm{DM}$ ) } \\
\hline $\mathrm{CP}(\%)$ & 15.7 & 15.4 & 16.9 & 16.9 \\
\hline NDF $(\%)$ & 49.4 & 35.4 & 31.4 & 29.6 \\
\hline NFC (\%) & 24.9 & 39.5 & 41.9 & 44.0 \\
\hline Fat $(\%)$ & 2.5 & 2.8 & 3.0 & 2.7 \\
\hline $\mathrm{Ca}(\mathrm{g})$ & 0.77 & 0.60 & 0.72 & 0.79 \\
\hline$P(g)$ & 0.37 & 0.49 & 0.46 & 0.47 \\
\hline $\mathrm{K}(\mathrm{g})$ & 1.88 & 1.54 & 1.44 & 1.47 \\
\hline
\end{tabular}

1 feeding period from $-56 \mathrm{~d}$ to $-14 \mathrm{~d} ;{ }^{2}$ feeding period from $-13 \mathrm{~d}$ to calving day; ${ }^{3}$ feeding period from $+1 \mathrm{~d}$ to $21 \mathrm{~d}$ of lactation;

${ }^{4}$ feeding period from $+22 \mathrm{~d}$ to $56 \mathrm{~d}$ of lactation; CP: crude protein; NDF: neutral detergent fiber; NFC: non-fiber carbohydrates; FB

$21 \% \mathrm{CP}$ - full-bodied blend with $21 \%$ of crude protein; BFMS - blended feed mixture supplement

Table 2. Composition and nutritive value of feed rations - herd B

\begin{tabular}{|c|c|c|c|c|}
\hline Components (kg/SM) & Dry period $\operatorname{diet}^{1}$ & Close-up diet ${ }^{2}$ & $\begin{array}{l}\text { Fresh diet }{ }^{3} \\
(34 \mathrm{~kg} \text { milk) }\end{array}$ & $\begin{array}{l}\text { Lactation diet }^{4} \\
(45 \mathrm{~kg} \text { milk) }\end{array}$ \\
\hline Corn silage & 2.37 & 3.90 & 6.60 & 8.99 \\
\hline Pressed sugarbeet pulp silage & - & - & 1.76 & 2.20 \\
\hline Alfalfa silage & 1.40 & 1.70 & 1.40 & 1.40 \\
\hline Grass silage & 1.81 & - & - & - \\
\hline Hay & - & 1.82 & 0.91 & 0.91 \\
\hline Straw & 4.50 & 1.35 & 1.35 & 0.90 \\
\hline Distiller's grain & - & 0.69 & 1.38 & 0.69 \\
\hline Ensiled corn grain & - & - & 2.80 & 3.50 \\
\hline Rapeseed meal & 0.88 & - & - & - \\
\hline FB $21 \% \mathrm{CP}$ & - & - & 3.10 & 8.85 \\
\hline BFMS & 0.25 & 3.09 & 2.21 & 0.22 \\
\hline Magnesium sulfate & 0.03 & - & - & - \\
\hline Rock salt & - & 0.10 & 0.13 & 0.08 \\
\hline Limestone & - & - & 0.15 & - \\
\hline \multicolumn{5}{|l|}{ Nutrients value (in $1 \mathrm{~kg}$ DM) } \\
\hline $\mathrm{CP}(\%)$ & 11.0 & 15.0 & 16.2 & 16.8 \\
\hline NDF (\%) & 54.5 & 39.8 & 34.1 & 31.6 \\
\hline NFC $(\%)$ & 21.0 & 32.3 & 38.4 & 40.9 \\
\hline Fat $(\%)$ & 2.8 & 3.1 & 2.9 & 2.7 \\
\hline $\mathrm{Ca}(\mathrm{g})$ & 0.59 & 0.49 & 0.96 & 0.99 \\
\hline$P(g)$ & 0.42 & 0.50 & 0.43 & 0.43 \\
\hline $\mathrm{K}(\mathrm{g})$ & 1.87 & 1.60 & 1.67 & 1.67 \\
\hline
\end{tabular}

Designations as shown in Table 1 
BCS on the dry-off day had a significant effect on fertility indices in herd A (Table 5). In the OK group $(<3.25 \mathrm{BCS})$, the lowest insemination index (1.80), the shortest period of insemination services $(25 \mathrm{~d})$, and days open $(87 \mathrm{~d})$ were recorded, as compared to the MID group (3.26-3.50 BCS), which was confirmed statistically $(\mathrm{P} \leq 0.05)$.

In herd $\mathrm{A}$, cows in the OK group $(<3.25 \mathrm{BCS})$, the shortest, statistically confirmed $(\mathrm{P} \leq 0.05)$, days open period (91 d) was recorded on calving day. In turn, in herd $\mathrm{B}$, negative relationships between fat condition at calving in the FAT group ( $>3.50 \mathrm{BCS})$ and the date of the first postpartum oestrus as well as days open were observed, although these differences were not statistically significant $(\mathrm{P}>0.05)$ (Table 6).

In herd $\mathrm{A}$, cows with $\mathrm{BCS}>3.50$ (the FAT group) had the longest, statistically confirmed $(\mathrm{P} \leq 0.05)$, uterine involution period ( $56 \mathrm{~d}$ ) during the first month of lactation $(30 \mathrm{~d})$. Moreover, in both herds in the FAT group $(>3.5 \mathrm{BCS})$, the longest anoestrus was recorded, while in herd B the longest days open period (153 d) and the latest date of the first postpartum oestrus $(100 \mathrm{~d})$ were found (Table 7). However, the differences were not statistically significant $(\mathrm{P}>0.05)$.

A decrease in body condition (group DE $\geq-0.25$ $\mathrm{BCS}$ ) during the dry period in herd A resulted in the extension of anoestrus, with the difference confirmed statistically $(\mathrm{P} \leq 0.05)$. Moreover, an improvement in the body condition in this period (group IM $\geq 0.25 \mathrm{BCS}$ ) in herd $\mathrm{B}$ resulted in an extension of the period of insemination services and a deterioration of the insemination index, with statistically significant differences $(\mathrm{P} \leq 0.05)$ (Table 8$)$.

No statistically significant difference $(\mathrm{P}>0.05)$ between the changes in BCS during the first month of lactation (30 d) and fertility indices (Table 9) was found. However, a deterioration of BCS (group DE $\geq-0.25$ $\mathrm{BCS}$ ) resulted in a prolongation of the insemination service period and the days open, as well as the insemination index in both herds.

Table 3. The effect of BCS at calving day on periparturient indices

\begin{tabular}{|c|c|c|c|c|c|c|}
\hline & \multicolumn{6}{|c|}{ Herd A } \\
\hline \multirow{3}{*}{ Periparturient indices } & \multicolumn{6}{|c|}{ BCS at calving day } \\
\hline & \multicolumn{2}{|c|}{$\mathrm{OK}(\mathrm{n}=52)$} & \multicolumn{2}{|c|}{$\mathrm{MID}(\mathrm{n}=36)$} & \multicolumn{2}{|c|}{ FAT $(\mathrm{n}=28)$} \\
\hline & $\overline{\boldsymbol{x}}$ & SD & $\overline{\boldsymbol{x}}$ & SD & $\bar{x}$ & $\mathrm{SD}$ \\
\hline Course of calving ( $1-5$ point scale) & 1.5 & 0.9 & 1.4 & 0.9 & 2.5 & 2.1 \\
\hline Date of calving (difference - days) & -3.5 & 6.1 & -2.0 & 4.1 & -9.5 & 0.7 \\
\hline \multirow[t]{5}{*}{ Colostrum density $\left(\mathrm{g} / \mathrm{cm}^{3}\right)$} & 1.043 & 0.01 & 1.042 & 0.01 & 1.048 & 0.02 \\
\hline & \multicolumn{6}{|c|}{ Herd B } \\
\hline & \multicolumn{6}{|c|}{ BCS at calving day } \\
\hline & \multicolumn{2}{|c|}{$\mathrm{OK}(\mathrm{n}=66)$} & \multicolumn{2}{|c|}{ MID $(n=30)$} & \multicolumn{2}{|c|}{ FAT $(n=12)$} \\
\hline & $\overline{\boldsymbol{x}}$ & SD & $\overline{\boldsymbol{x}}$ & SD & $\bar{x}$ & $\mathrm{SD}$ \\
\hline Course of calving ( $1-5$ point scale) & 3.0 & 2.0 & 2.75 & 0.9 & 2.9 & 0.7 \\
\hline
\end{tabular}

BCS at calving day - $\mathrm{OK} \leq 3.25$ points; MID 3.26-3.50 points; $\mathrm{FAT}>3.50$ points

Table 4. The relationship between changes in BCS during dry period and periparturient indices

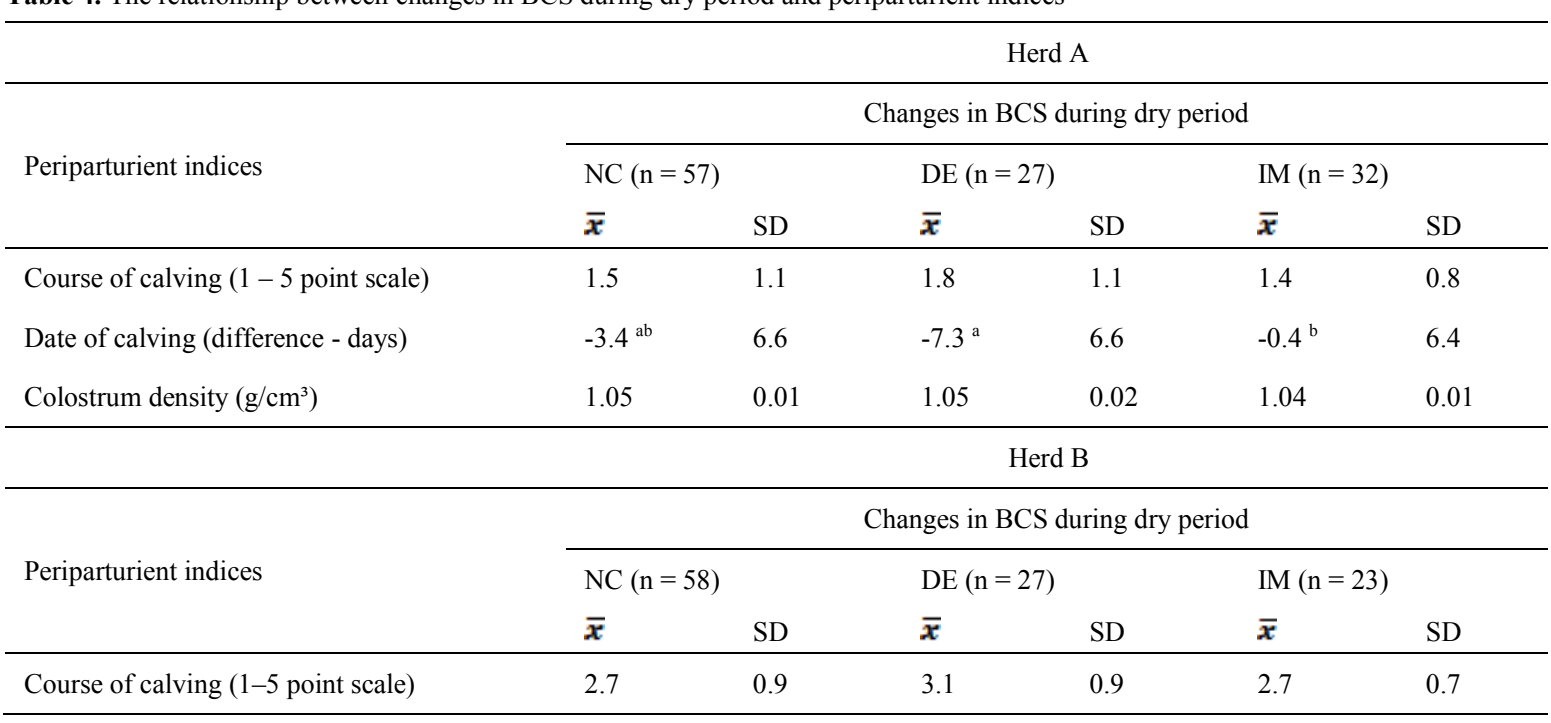

Changes in BCS from dry-off day to calving day - NC $<0.25 \mathrm{BCS}$ points; $\mathrm{DE} \geq-0.25 \mathrm{BCS}$ points; IM $\geq 0.25 \mathrm{BCS}$ points 
Table 5. The relationship between BCS at dry-off day and fertility indices

\begin{tabular}{|c|c|c|c|c|c|c|}
\hline \multirow{4}{*}{ Fertility indices } & \multicolumn{6}{|c|}{ Herd A } \\
\hline & \multicolumn{6}{|c|}{ BCS at dry-off day } \\
\hline & \multicolumn{2}{|c|}{$\mathrm{OK}(\mathrm{n}=72)$} & \multicolumn{2}{|c|}{$\operatorname{MID}(n=44)$} & \multicolumn{2}{|c|}{ FAT $(n=0)$} \\
\hline & $\bar{x}$ & SD & $\bar{x}$ & $\mathrm{SD}$ & $\bar{x}$ & SD \\
\hline $1^{\text {st }}$ oestrus (d) & 37 & 20 & 50 & 23 & . & . \\
\hline Uterine involution (d) & 38 & 10 & 41 & 11 & . & . \\
\hline Anoestrus (d) & 62 & 11 & 69 & 10 & . & . \\
\hline Period of insemination services (d) & $25^{\mathrm{a}}$ & 26 & $53^{b}$ & 37 & . & . \\
\hline Days open (d) & $87^{\mathrm{a}}$ & 24 & $122^{b}$ & 34 & . & . \\
\hline \multirow[t]{2}{*}{ Insemination index } & $1.80^{\mathrm{a}}$ & 0.69 & $2.40^{\mathrm{b}}$ & 0.84 & . & . \\
\hline & \multicolumn{6}{|c|}{ Herd B } \\
\hline \multirow{3}{*}{ Fertility indices } & \multicolumn{6}{|c|}{ BCS at dry-off day } \\
\hline & \multicolumn{2}{|c|}{$\mathrm{OK}(\mathrm{n}=66)$} & \multicolumn{2}{|c|}{$\operatorname{MID}(n=30)$} & \multicolumn{2}{|c|}{ FAT $(n=12)$} \\
\hline & $\bar{x}$ & $\mathrm{SD}$ & $\bar{x}$ & $\mathrm{SD}$ & $\bar{x}$ & $\mathrm{SD}$ \\
\hline $1^{\text {st }}$ oestrus (d) & 83 & 22 & 91 & 38 & 88 & 41 \\
\hline Anoestrus (d) & 86 & 24 & 97 & 33 & 109 & 37 \\
\hline Period of insemination services (d) & 49 & 47 & 40 & 47 & 22 & 36 \\
\hline Days open (d) & 134 & 37 & 136 & 54 & 131 & 43 \\
\hline Insemination index & 2.20 & 1.10 & 2.11 & 1.24 & 1.58 & 0.93 \\
\hline
\end{tabular}

BCS at dry-off day - OK $\leq 3.25$ points; MID $3.25-3.50$ points; FAT $>3.50$ points

Table 6. The relationship between BCS at calving day and fertility indices

\begin{tabular}{|c|c|c|c|c|c|c|}
\hline \multirow{4}{*}{ Fertility indices } & \multicolumn{6}{|c|}{ Herd A } \\
\hline & \multicolumn{6}{|c|}{$\mathrm{BCS}$ at calving } \\
\hline & \multicolumn{2}{|c|}{$\mathrm{OK}(\mathrm{n}=52)$} & \multicolumn{2}{|c|}{$\operatorname{MID}(n=36)$} & \multicolumn{2}{|c|}{ FAT $(\mathrm{n}=28)$} \\
\hline & $\bar{x}$ & $\mathrm{SD}$ & $\bar{x}$ & $\mathrm{SD}$ & $\bar{x}$ & $\mathrm{SD}$ \\
\hline $1^{\text {st }}$ oestrus (d) & 37 & 21 & 36 & 24 & 36 & 39 \\
\hline Uterine involution (d) & 40 & 11 & 39 & 10 & 35 & 10 \\
\hline Anoestrus (d) & 63 & 14 & 60 & 11 & 74 & 16 \\
\hline Period of insemination services (d) & 29 & 29 & 44 & 47 & 64 & 4 \\
\hline Days open (d) & $91^{\mathrm{a}}$ & 29 & $103^{\text {ab }}$ & 45 & $138^{\mathrm{b}}$ & 19 \\
\hline \multirow[t]{2}{*}{ Insemination index } & 1.89 & 0.80 & 2.00 & 1.13 & 2.50 & 0.71 \\
\hline & \multicolumn{6}{|c|}{ Herd B } \\
\hline \multirow{3}{*}{ Fertility indices } & \multicolumn{6}{|c|}{ BCS at calving } \\
\hline & \multicolumn{2}{|c|}{$\mathrm{OK}(\mathrm{n}=66)$} & \multicolumn{2}{|c|}{$\operatorname{MID}(\mathrm{n}=30)$} & \multicolumn{2}{|c|}{$\operatorname{FAT}(\mathrm{n}=12)$} \\
\hline & $\bar{x}$ & $\mathrm{SD}$ & $\bar{x}$ & $\mathrm{SD}$ & $\bar{x}$ & $\mathrm{SD}$ \\
\hline $1^{\text {st }}$ oestrus (d) & 89 & 36 & 83 & 40 & 94 & 35 \\
\hline Anoestrus (d) & 89 & 36 & 103 & 40 & 103 & 30 \\
\hline Period of insemination services (d) & 44 & 57 & 21 & 34 & 41 & 46 \\
\hline Days open (d) & 132 & 31 & 123 & 45 & 144 & 49 \\
\hline Insemination index & 2.33 & 1.53 & 1.59 & 1.01 & 2.04 & 1.11 \\
\hline
\end{tabular}

BCS at calving day - $\mathrm{OK} \leq 3.25$ points; $\mathrm{MID} 3.25-3.50$ points; FAT $>3.50$ points 
Table 7. The relationship between BCS during the first month of lactation ( $30 \mathrm{~d})$ and fertility indices

\begin{tabular}{|c|c|c|c|c|c|c|}
\hline \multirow{4}{*}{ Fertility indices } & \multicolumn{6}{|c|}{ Herd A } \\
\hline & \multicolumn{6}{|c|}{ BCS at day 30 of lactation } \\
\hline & \multicolumn{2}{|c|}{$\mathrm{OK}(\mathrm{n}=52)$} & \multicolumn{2}{|c|}{$\operatorname{MID}(\mathrm{n}=36)$} & \multicolumn{2}{|c|}{ FAT $(n=28)$} \\
\hline & $\bar{x}$ & $\mathrm{SD}$ & $\bar{x}$ & $\mathrm{SD}$ & $\bar{x}$ & SD \\
\hline $1^{\text {st }}$ oestrus $(\mathrm{d})$ & 38 & 21 & 35 & 21 & 6 & . \\
\hline Uterine involution (d) & $41^{\mathrm{ab}}$ & 11 & $38^{\mathrm{b}}$ & 8 & $56^{\mathrm{a}}$ & . \\
\hline Anoestrus (d) & 64 & 14 & 59 & 11 & 69 & . \\
\hline Period of insemination services (d) & 30 & 33 & 37 & 34 & 1 & . \\
\hline Days open (d) & 94 & 31 & 95 & 35 & 69 & . \\
\hline \multirow[t]{2}{*}{ Insemination index } & 1.93 & 0.83 & 1.93 & 0.92 & 1.00 & . \\
\hline & \multicolumn{6}{|c|}{ Herd B } \\
\hline \multirow{3}{*}{ Fertility indices } & \multicolumn{6}{|c|}{ BCS at day 30 of lactation } \\
\hline & \multicolumn{2}{|c|}{$\mathrm{OK}(\mathrm{n}=66)$} & \multicolumn{2}{|c|}{$\operatorname{MID}(n=30)$} & \multicolumn{2}{|c|}{$\operatorname{FAT}(\mathrm{n}=12)$} \\
\hline & $\bar{x}$ & $\mathrm{SD}$ & $\bar{x}$ & SD & $\bar{x}$ & $\mathrm{SD}$ \\
\hline $1^{\text {st }}$ oestrus $(\mathrm{d})$ & 77 & 33 & 85 & 40 & 100 & 32 \\
\hline Anoestrus (d) & 82 & 28 & 102 & 37 & 109 & 29 \\
\hline Period of insemination services (d) & 47 & 54 & 25 & 36 & 44 & 49 \\
\hline Days open $(d)$ & 128 & 47 & 126 & 41 & 153 & 56 \\
\hline Insemination index & 2.40 & 1.52 & 1.70 & 1.02 & 2.00 & 1.08 \\
\hline
\end{tabular}

BCS during the first month of lactation - OK $\leq 3.25$ points; MID 3.25-3.50 points; FAT $>3.50$ points

Table 8. Changes in BCS during dry period and fertility indices

\begin{tabular}{|c|c|c|c|c|c|c|}
\hline \multirow{4}{*}{ Fertility indices } & \multicolumn{6}{|c|}{ Herd A } \\
\hline & \multicolumn{6}{|c|}{ Changes in BCS during dry period } \\
\hline & \multicolumn{2}{|c|}{$\mathrm{NC}(\mathrm{n}=57)$} & \multicolumn{2}{|c|}{$\mathrm{DE}(\mathrm{n}=27)$} & \multicolumn{2}{|c|}{$\mathrm{IM}(\mathrm{n}=32)$} \\
\hline & $\bar{x}$ & $\mathrm{SD}$ & $\bar{x}$ & SD & $\bar{x}$ & $\mathrm{SD}$ \\
\hline $1^{\text {st }}$ oestrus $(d)$ & 39 & 19 & 46 & 27 & 38 & 22 \\
\hline Uterine involution (d) & 39 & 10 & 41 & 13 & 37 & 8 \\
\hline Anoestrus (d) & $62^{\text {a }}$ & 13 & $72^{b}$ & 10 & $60^{\mathrm{a}}$ & 5 \\
\hline Period of insemination services (d) & 36 & 36 & 25 & 19 & 25 & 24 \\
\hline Days open (d) & 98 & 35 & 97 & 19 & 85 & 26 \\
\hline \multirow[t]{2}{*}{ Insemination index } & 2.04 & 0.79 & 1.78 & 0.67 & 1.81 & 0.75 \\
\hline & \multicolumn{6}{|c|}{ Herd B } \\
\hline \multirow{3}{*}{ Fertility indices } & \multicolumn{6}{|c|}{ Changes in BCS during dry period } \\
\hline & \multicolumn{2}{|c|}{$\mathrm{NC}(\mathrm{n}=58)$} & \multicolumn{2}{|c|}{$\mathrm{DE}(\mathrm{n}=27)$} & \multicolumn{2}{|c|}{$\mathrm{IM}(\mathrm{n}=23)$} \\
\hline & $\bar{x}$ & SD & $\bar{x}$ & SD & $\bar{x}$ & $\mathrm{SD}$ \\
\hline $1^{\text {st }}$ oestrus $(d)$ & 83 & 40 & 91 & 43 & 94 & 29 \\
\hline Anoestrus (d) & 98 & 33 & 113 & 40 & 96 & 27 \\
\hline Period of insemination services (d) & $31^{\mathrm{ab}}$ & 43 & $11^{\mathrm{b}}$ & 19 & $60^{\text {a }}$ & 48 \\
\hline Days open (d) & 128 & 47 & 123 & 42 & 156 & 47 \\
\hline Insemination index & $1.86^{\mathrm{ab}}$ & 1.20 & $1.33^{\mathrm{b}}$ & 0.62 & $2.50^{\mathrm{a}}$ & 1.09 \\
\hline
\end{tabular}

a,b - means with different letters are significantly different; changes in BCS from dry-off day to calving day - NC $<0.25$ points; DE $\geq-0.25$ points; IM $\geq 0.25$ points 
Table 9. The effect of BCS changes in the period from dry-off day to day 30 of lactation on fertility indices

\begin{tabular}{|c|c|c|c|c|c|c|}
\hline \multirow{4}{*}{ Fertility indices } & \multicolumn{6}{|c|}{ Herd A } \\
\hline & \multicolumn{6}{|c|}{ Changes in BCS to day 30 of lactation } \\
\hline & \multicolumn{2}{|c|}{$\mathrm{NC}(\mathrm{n}=57)$} & \multicolumn{2}{|c|}{$\operatorname{DE}(n=27)$} & \multicolumn{2}{|c|}{$\mathrm{IM}(\mathrm{n}=32)$} \\
\hline & $\bar{x}$ & SD & $\bar{x}$ & $\mathrm{SD}$ & $\overline{\boldsymbol{x}}$ & $\mathrm{SD}$ \\
\hline $1^{\text {st }}$ oestrus $(\mathrm{d})$ & 36 & 23 & 38 & 22 & 38 & 19 \\
\hline Uterine involution (d) & 41 & 11 & 38 & 11 & 39 & 10 \\
\hline Anoestrus (d) & 64 & 15 & 64 & 12 & 60 & 11 \\
\hline Period of insemination services (d) & 30 & 31 & 39 & 37 & 32 & 34 \\
\hline Days open (d) & 94 & 26 & 103 & 42 & 91 & 35 \\
\hline \multirow[t]{2}{*}{ Insemination index } & 1.87 & 0.83 & 2.13 & 0.92 & 1.90 & 0.88 \\
\hline & \multicolumn{6}{|c|}{ Herd B } \\
\hline \multirow{3}{*}{ Fertility indices } & \multicolumn{6}{|c|}{ Changes in BCS to day 30 of lactation } \\
\hline & \multicolumn{2}{|c|}{$\mathrm{NC}(\mathrm{n}=58)$} & \multicolumn{2}{|c|}{$\mathrm{DE}(\mathrm{n}=27)$} & \multicolumn{2}{|c|}{$\mathrm{IM}(\mathrm{n}=23)$} \\
\hline & $\bar{x}$ & SD & $\bar{x}$ & SD & $\bar{x}$ & $\mathrm{SD}$ \\
\hline $1^{\text {st }}$ oestrus $(\mathrm{d})$ & 90 & 39 & 85 & 35 & 83 & 31 \\
\hline Anoestrus (d) & 105 & 38 & 96 & 27 & 93 & 23 \\
\hline Period of insemination services $(d)$ & 27 & 40 & 42 & 46 & 40 & 40 \\
\hline Days open (d) & 131 & 48 & 138 & 45 & 134 & 40 \\
\hline Insemination index & 1.72 & 1.02 & 2.13 & 1.20 & 2.03 & 1.26 \\
\hline
\end{tabular}

Change in BCS from dry-off day to day 30 of lactation - $\mathrm{NC}<0.25$ points; $\mathrm{DE} \geq-0.25$ points; $\mathrm{IM} \geq 0.25$ points

\section{Discussion}

Dystocia, next to diarrhoea and pneumonia occurring in rearing period, is considered to be the primary cause of calf wastage (24). Its main consequences include reduced milk yield, deterioration of milk technological quality (increased somatic cell count) (4) as well as a decrease in fertility indices (1). Primary factors affecting the course of calving are connected with the sex of calves and their body weight at birth, the number of born animals (single vs. twin birth), lactation rank of the dam, and numerous genetic factors $(4,20)$. Moreover, this study showed some relation between the body condition of cows on calving day and the course of calving, as well as a negative dependence between deterioration in BCS of -0.25 point during the dry period and this trait; however, the differences were not statistically significant. Moreover, in herd $\mathrm{A}$, the deterioration of $\mathrm{BCS}(\mathrm{DE} \geq-0.25)$ in this period accelerated the planned date of calving by $7.3 \mathrm{~d}$. Roche et al. (26) showed that limited research results confirm the statistically significant effect of BCS on the dry-off day, calving day, or its deterioration in the course of calving. In our opinion a decrease in body condition during this period resulted from the reduction in the availability of nutrients to the foetus, which may have accelerated the date of calving. Adamski (1) recorded a significant positive correlation between BCS on the calving day and dystocia, particularly in primiparous cows. Moreover, Gearhart et al. (12) showed an increased risk of dystocia in cows with a deteriorating body condition during the dry period. Nogalski (21) presented a negative effect of too weak condition (<3.0 BCS), while Borkowska and Januś (5) - too fat BCS $(>3.5)$ at calving as the main cause for dystocia. These authors attribute main causes of this complication to insufficiently strong bearing-down efforts and to an increased body weight of calves at birth, respectively. Moreover, incidence of dystocia resulted in a further prolonged deterioration of the body condition during lactation (4). In turn, Przysucha and Grodzki (24) found no significant relationship between the body weight and body condition, as well as the length of pregnancy, while they indicated breed and calving season among the main factors influencing this trait.

Currently, the main objectives in dairy cattle rearing and breeding are connected, first of all, with the maintenance of high herd fertility (7). A delayed first postpartum oestrus $(>40$ d) is connected with deterioration of fertility indices in cows and economic losses for breeders (9). The effect of BCS, reflecting the energy status and fertility, has been presented by Roche et al. (26). This study showed no statistically significant effect of the body condition on the calving day or its changes during the investigated periods on the date of the first postpartum oestrus. However, cows which showed a decrease of -0.25 BCS point between the dry period and the calving day had the first oestrus the latest. The association of these processes with 
a return to ovulation has been well studied $(7,13,26)$; however, their influence on the reproductive performance is less known. We suggested that the BCS on calving day strongly affected biochemical blood indices characterising lipid and carbohydrate metabolism in the first month of lactation with only partly a negative effect on the reproductive performance. Moreover, our results suggested that cows could have good welfare, as implied by slight changes in their condition and the number of animals in experimental groups in the dry period and on the calving day. Holly et al. (13) showed that the negative energy balance connected with a deteriorated body condition in cows during the periparturient period caused a lower concentration of IGF-I and LH, required for the development of ovarian follicles, which, at the same time, extended the period of return to ovarian activity, disturbed the cyclicity of ovulation, and deteriorated the quality of oocytes, as reflected by biochemical changes in the composition of the follicular fluid.

The return to the previous anatomical size of the genitalia is considered to mark the end of puerperium (17). This physiological state is attained after complete uterine involution, which is connected with its shrinking back to the size before pregnancy, along with the return to the weight and blood supply, regeneration of the mucosa, and removal of its redundant fragments, the so-called lochia (17). Anatomical and histological involution of the uterus in healthy cows lasts approx. $40-50 \mathrm{~d}$ after calving. The rate of uterine involution may depend on the age of cows, their breed, and nutrition in transition period, while its delay may be related to metritis (17). This study showed a negative effect of too fatty body (>3.50 BCS) in the first month of lactation, indicating a potential negative energy balance in this group of animals, which directly affects changes in the hormonal balance determining postpartum fertility indices, including uterine involution. Moreover, Peter et al. (22) showed a negative effect of a very low BCS $(<3.25)$, which in combination with a negative energy balance in early lactation inhibits pulsatile release of the luteinising hormone stimulating the development of the corpus luteum, as well as hinders ovarian function, thus leading to a reduced oestradiol secretion, and delays uterine involution. Breeders identify anoestrus, i.e. the period between calving and the first artificial insemination service, based on the date of uterine involution and the occurrence of physiological oestrus cycles. This practice seems to be justified by the results of this study, showing a statistically significant effect of a deterioration in BCS of -0.25 point in the period from the dry-off day to calving on the extension of anoestrus $(72 \mathrm{~d})$. Moreover, in the $\mathrm{OK}$ group $(\leq 3.25 \mathrm{BCS})$ the shortest period of insemination services was observed on the dry-off day, while in the IM group $(\geq 0.25 \mathrm{BCS})$ the longest period of insemination services was recorded in the period from the dry-off day to calving. Jankowska and Sawa (14) also reported a positive correlation between an excessively good body condition (reserve fat) towards the end of lactation and in the dry period and the length of the period of insemination services. For cows with BCS $>3.5$ during the transition from late gestation to early lactation, considerable amounts of adipose tissue are mobilised, resulting in elevated plasma nonesterified fatty acids (NEFA) supporting increased energy requirements in dairy cows and at the same time negative energy balance (NEB) (19). Circulating NEFA can be oxidised in the hepatocytes or exported as constituents of very low density lipoproteins (VLDL). However, postpartum release of NEFA from adipose tissue mostly exceeds the needs and oxidation capabilities of the liver (19) and causes formation of ketone bodies including $\beta$-hydroxybutyrate (BHBA) and reesterification to triglycerides (TG). The latter are stored in hepatocytes and implicate the development of fatty liver, reduced metabolic function, health status, productivity, and reproductive performance, as well as incidence and severity of metabolic disorders and infectious diseases (2). NEB delays the start of the ovarian activity and reduces the number of oestrus cycles, extending the days open (28). Moreover, a negative energy balance, metabolic diseases, and infections of the uterus are the major weakness of the secretion of luteinising hormone (LH), which affects the dominant follicle maturation and ovulation (9). Recent studies have also indicated that the resulting energy deficit determines the quality of oocytes, which reflect changes in the biochemical composition of follicular fluid (16). Many authors agree that determination of BCS in high-yielding dairy cows could minimise the effect of negative energy balance, which is one of the most important reasons for poor reproductive performance (9).

Negative energy balance has an adverse effect on hormonal balance; it impairs progesterone secretion and is a major cause of abnormal development of Graafian follicles. Moreover, energy deficit delays the onset of ovarian activity and reduces the number of oestrus cycles, thus lengthening the days open (24). Furthermore, negative energy balance, metabolic disorders, and metritis are the main causes of reduced secretion of the luteinising hormone (LH), which influences the maturation of the dominant ovarian follicle and the occurrence of ovulation (12). This study showed the effect of BCS at dry-off and calving on the length of the days open in herd A. In the group of cows with too fat BCS $(>3.25)$ as compared to the OK groups (BCS $\leq 3.25$ ), the longest days open period was observed, with the statistically confirmed differences. These results seem to indicate that in this experimental group cows exhibited the best energy status, which directly influenced fertility indices. Moreover, Butler and Smith (6) suggested that an excessively good body condition ( $>3.5$ BCS) at calving is correlated with a limitation of dry matter uptake, which directly 
aggravates the negative energy in the early lactation, having an adverse effect on the return to ovarian activity and effectiveness of fertilisation. According to Adamski (1), both improvement and deterioration of BCS during the dry period have a negative effect on the days open. It confirmed that change of BCS influences herd reproductive performance during the pre and postpartum period.

The insemination index is another important indicator, facilitating the assessment of fertility in a dairy cattle herd. Its proper value should be around 1.6 (1). Chagas et al. (9) showed a negative relationship between BCS at calving and its changes in the early lactation and the duration of return to ovarian activity, connected with reduced LH secretion and lowered ovarian follicle excitability to the action of gonadotropic hormones. In the opinion of Roche et al. (25), a loss of more than 0.5 BCS during early lactation reduces the chance of successful insemination in the first 6 weeks after calving, which was not confirmed in this study. However, it was shown that the body condition on the dry-off day had a statistically significant effect on the insemination index in herd B. Moreover, improvement of $\geq 0.25$ point the body condition in the period from the dry-off day to calving caused a statistically significant deterioration of this index (2.5). Literature data indicates that some of the main causes of this phenomenon are connected with an energy deficit, delayed return to ovarian activity after calving, problems with embryo implantation, or its morphological development (1).

Moreover, we observed in both herds different results associated with fertility indices, which could be associated with other factors of animal welfare or the number of experimental animals.

The results do not provide an answer to the proposed research hypothesis. However, they indicate that the body condition on the dry-off day and at calving, as well as its deterioration in the first month of lactation, have a considerable effect on fertility indices in dairy cows, thus confirming the advisability of its regular monitoring during routine operations connected with the management of a dairy cattle herd. Moreover, they also identify ranges of body condition scores for dairy cows in the most sensitive periparturient period, which should be $3.25 \mathrm{BCS}$ on the dry-off day and at calving, as well as its admissible deterioration to $0.25 \mathrm{BCS}$ in the first month of lactation.

Conflict of Interests Statement: The authors declare that there is no conflict of interests regarding the publication of this article.

Financial Disclosure Statement: This scientific work was financed from a research project No. 70/2014/U.

Animal Rights Statement: The authors declare that the experiments on animals were conducted in accordance with local Ethical Committee laws and regulations as regards care and use of laboratory animals.

\section{References}

1. Adamski M.: Kondycja krów w okresie okołoporodowym a poziom wybranych parametrów krwi i płodności. Publication of the Wrocław University of Environmental and Life Sciences, Wrocław, 2010, pp. 7-84.

2. Akbar H., Grala T.M., Vailati Riboni M., Cardoso F.C., Verkerk G., McGowan J., Macdonald K., Webster J., Schutz K., Meier S., Matthews L., Roche J.R., Loor J.J.: Body condition score at calving affects systemic and hepatic transcriptome indicators of inflammation and nutrient metabolism in grazing dairy cows. J. Dairy Sci 2015, 98, 1019-1032.

3. Banos G., Coffey M.P.: Genetic association between body energy measured throughout lactation and fertility in dairy cattle. Animal 2010, 4, 189-199.

4. Berry D.P., Roche J.R., Coffey M.P.: Body condition score and fertility-more than just a feeling. Fertility in dairy cows Bridging the gaps Liverpool Hope University, Liverpool, UK, 2007, pp. 107-118.

5. Borkowska D., Januś E.: Evaluation of the relationship between body conditions of high-yield Black-and-White Polish HolsteinFriesian cows and their productivity. Med Weter 2002, 58, 138-140.

6. Butler W.R., Smith R.D.: Interrelationships between energy balance and postpartum reproductive function in dairy cattle. J Dairy Sci 1989, 72, 767-783.

7. Carvalho P.D., Souza A.H., Amundson M.C., Hackbart K.S., Fuenzalida M.J., Herlihy M.M., Ayres H., Dresch A.R., Vieira L.M., Guenther J.N., Grummer R.R., Fricke P.M., Shaver R.D., Wiltbank M.C.: Relationships between fertility and postpartum changes in body condition and body weight in lactating dairy cows. J Dairy Sci 2014, 97, 3666-3683.

8. Castro N., Kawashima C., van Dorland H.A., Morel I., Miyamoto A., Bruckmaier R.M.: Metabolic and energy status during the dry period is crucial for the resumption of ovarian activity postpartum in dairy cows. J Dairy Sci 2012, 95, 5804-5812.

9. Chagas L.M., Bass J.J., Blache C.R., Burke J.K., Kay D.R., Lindsay M.C., Lucy G.B., Martin S., Meier F.M., Rhodes J.R., Roche W.W., Thatcher R., Webb R.: New perspectives on the roles of nutrition and metabolic priorities in the subfertility of high-producing dairy cows. J Dairy Sci 2007, 90, 4022-4032.

10. Edmondson A.J., Lean I.J., Weave L.D., Farvel T., Webste G.: A body condition scoring chart for Holstein dairy cows. J Dairy Sci 1989, 72, 68-78.

11. Fair T.: Mammalian oocyte development: checkpoints for competence. Reprod Fertil Dev 2010, 22, 13-20.

12. Gearhart M.A., Curtis C.R., Erb H.N., Smith R.D., Sniffen C.J., Chase L.E., Cooper M.D.: Relationship of changes in condition score to cow health in Holsteins. J Dairy Sci 1990, 73, 3132-3140.

13. Holly J.M.P., Wass J.A.H.: Insulin-like growth factors; autocrine, paracrine or endocrine? New perspectives of the somatomedin hypothesis in the light of recent developments. J Endocrinol 1989, 122, 611-618.

14. Jankowska M., Sawa A., Gierszewski R.: Effect of some factors on cow's body conditions and fertility. Rocz. Nauk. PTZ 2012, 2, 9-16.

15. Kawashima C., Sakaguchi M., Suzuke T., Sasamoto Y., Takahashi Y., Matsui M., Miyamoto A.: Metabolic profiles in ovulatory and anovulatory primiparous dairy cows during the first follicular wave postpartum. J Reprod Dev 2007, 53, $113-120$.

16. Konigsson K., Savoini G., Govoni N., Invernizzi G., Prandi A., Kindahl H., Veronesi M.C.: Energy balance, leptin, NEFA and IGF-I plasma concentrations and resumption of post-partum 
ovarian activity in swedish red and white breed cows. Acta Vet Scand 2008, 50, 1-7.

17. Krzymowski T.: Fizjologia zwierząt. Państwowe Wydawnictwo Rolnicze i Leśne 1998.

18. Liang D., Wood C.L., McQuerry K.J., Ray D.L., Clark J.D., Bewley J.M.: Influence of breed, milk production, season, and ambient temperature on dairy cow reticulorumen temperature. J Dairy Sci 2013, 96, 5072-5081.

19. Locher L., Häussler S., Laubenthal L., Singh S.P., Winkler J., Kinoshita A., Kenéz A., Rehage J., Huber K., Sauerwein H., Dänicke S.: Effect of increasing body condition on key regulators of fat metabolism in subcutaneous adipose tissue depot and circulation of nonlactating dairy cows. J. Dairy Sci 2015, 98, 1057-1068.

20. Mee J.F.: Prevalence and risk factors for dystocia in dairy cattle. Vet J 2008, 176, 93-101.

21. Nogalski Z.: Body condition of Black and White cows at calving versus their performance. Rocz. Nauk. PTZ 2005, 1, 85-94.

22. Peter A.T., Vos P.L.A.M., Ambrose D.J.: Postpartum anestrus in dairy cattle. Theriogenology 2009, 71, 1333-1342.

23. Piccione G., Refinetti R.: Thermal chronobiology of domestic animal. Front Biosci 2003, 8, 258-264.

24. Przysucha T., Grodzki H.: Influence of chosen factors on beef breed cows' pregnancy length. Rocz. Nauk. PTZ 2009, 5, 65-72.
25. Roche J.R., Dillon P.G., Stockdale C.R., Baumgard L.H., van Baale M.J.: Relationships among international body condition scoring systems. J Dairy Sci 2004, 87, 3076-3079.

26. Roche J.R., Friggens N.C., Kay J.K., Fisher M.W., Stafford K.J., Berry D.P.: Body condition score and its association with dairy cow productivity, health, and welfare. J Dairy Sci 2009, 92, 5769-5801.

27. Roche J.R., Macdonald K.A., Burke C.R., Lee J.M., Berry D.P.: Associations among body condition score, body weight and reproductive performance in seasonal-calving dairy cattle. J Dairy Sci 2007, 90, 376-391.

28. Roche J.R., Macdonald K.A., Schütz K.A., Matthews L.R., Verkerk G.A., Meier S., Loor J.J., Rogers A.R., McGowan J., Morgan S.R., Taukiri S., Webster R.J.: Calving body condition score affects indicators of health in grazing dairy cows. J. Dairy Sci 2013, 96, 5811-5825.

29. Shehab-El-Deen M.A., Leroy J.L., Fadel M.S., Saleh S.Y., Maes D., van Soom A.: Biochemical changes in the follicular fluid of the dominant follicle of high producing dairy cows exposed to heat stress early post-partum. Anim Reprod Sci 2010, $117,189-200$.

30. Stefaniak T., Jawor P.: The most important causes of failure of passive transfer in calves kept in dairy farms. Folia Univ Agric Stetin Zootechnica 2006, 250, 45-50. 